\section{ЗАЙНЯТІСТЬ НАСЕЛЕННЯ ТА СУЧАСНІ ТЕНДЕНЦІЇ РОЗВИТКУ СУСПІЛЬСТВА ПІД ВПЛИВОМ ПАНДЕМІї COVID-19}

ОГНЕВА А. В., здобувач вищої освіти ступеня доктора філософії спеціальності 051 «Економіка», Донецький державний університет управління

\section{EMPLOYMENT AND CURRENT TRENDS IN THE DEVELOPMENT OF SOCIETY UNDER THE INFLUENCE OF THE COVID-19 PANDEMIC}

\author{
OHNIEVA A., \\ Post-graduate Student in the \\ specialty 051 "Economics" \\ Donetsk State University of \\ Management
}

У статті досліджено вплив пандемії COVID-19 на розвиток сучасних тенденцій суспільства. Значну увагу приділено питанням трансформації зайнятості та можливим стадіям спаду безробіття. Визначено проблему невідповідності професійних знань, умінь та навичок працівників сучасним вимогам. Рекомендовано низку заходів щодо запобігання проблем пов'язаних з дефіцитом кваліфікованих працівників, масовим безробіттям та зростанням нерівності.

Ключові слова: пандемія; зайнятість; безробіття; навички; тенденції розвитку.

В статье исследовано влияние пандемии COVID-19 на развитие современных тенденций общества. Значительное внимание уделено вопросам трансформации занятости и возможным стадиям спада безработицы. Определена проблема несоответствия профессиональных знаний, умений и навыков работников современным требованиям. Рекомендуется ряд мер по предотвращению проблем, связанных с дефицитом квалифицированных работников, массовой безработицей и ростом неравенства.

Ключевые слова: пандемия; занятость; безработица; навыки; тенденции развития.

The article examines the impact of the COVID-19 pandemic on the development of current trends in society. Considerable attention is paid to issues of employment transformation and possible stages of unemployment decline. The problem of non-compliance of professional knowledge, skills and abilities of employees with modern requirements is identified. Some measures are recommended to prevent problems with a shortage of skilled workers, mass unemployment and increasing inequality.

Keywords: pandemic; employment; unemployment; development trends; skills.

Постановка проблеми. Сучасне українське суспільство переживає складний етап економічних і соціальних перетворень. У зв'язку з кризовою ситуацією, викликаною пандемією COVID-19, український бізнес у 2020 році опинився на межі виживання [1, с. 7]. Укріплюються такі негативні соціальні явища як безробіття, низький рівень життя, соціальне розшарування. За даними Державної служби статистики України внутрішній валовий продукт у III кварталі 2020 року зменшився на 3,5\% у порівнянні з III кварталом 2019 року [2]. Тобто, карантинні заходи, які були застосовані країнами через спалах 
пандемії COVID-19 призвели до розвитку кризових явищ в економіці, які безпосередньо вплинули й на ринок праці.

Зайнятість та безробіття - два ключові агреговані показники ринку праці. Останні три роки показник зайнятості залишався стабільно високий, а показник безробіття мав чітку тенденцію до зниження, проте пандемія перегорнула робочий світ з ніг на голову, залишивши мільйони людей без роботи та змусивши мільйони працювати дистанційно. Професії, що мали попит ще в недалекому минулому нині втратили свою актуальність та натомість з'явилися зовсім нові спеціальності.

Головний тренд 2020 року на ринку праці перехід до дистанційної або надомної роботи. Дослідження міжнародної компанії Ernst \& Young Global Limited «Дистанційна робота в Україні» демонструє, що у зв'язку з пандемією COVID-19 кількість компаній, які внесли зміни до політики щодо дистанційної роботи склала 88\% [3, с. 13]. Праця з дому стала нормою для більшості офісних працівників. Дистанційна робота прирівнюється до звичайної зайнятості. В умовах кризи деякі компанії скорочуються, перерозподіляють свої ресурси, змінюють пріоритети в мисленні, вимоги до персоналу. Чим краще сьогодні компанії розуміють в якому напрямку рухатися, який персонал необхідний, які знання, вміння та навички будуть потрібні в майбутньому, тим більш конкурентоспроможними вони зможуть бути на ринку праці.

Аналіз останніх досліджень і публікацій. Проблемам зайнятості та безробіття присвячено чимало праць українських та закордонних науковців. Окремі аспекти формування знань, умінь та навичок майбутніх поколінь досліджували такі вчені, як М. О. Сокол, О. М. Царик, 3. С. Сокол [4], О. А. Грішнова [5], А. М. Колот [6]. Водночас проблеми пов'язані з дефіцитом кваліфікованих працівників, які мають попит у сучасних умовах на ринку праці недостатньо висвітлено в науковій літературі.

Мета статті полягає в аналізі впливу світової пандемії COVID-19 на сучасні тенденції розвитку суспільства й зайнятість населення та дослідження основних затребуваних професійних навичок працівників.

Виклад основного матеріалу дослідження. Зайнятість - не заборонена законодавством діяльність осіб, пов'язана із задоволенням їх особистих та суспільних потреб з метою одержання доходу у грошовій або іншій формі [7]. Зайнятість відіграє одну із найважливіших ролей у забезпеченні економічного зростання країни. Зміна структури та рівня зайнятості відбиває глибинні соціальноекономічні зрушення в економіці й суспільстві.

Два взаємопов'язані процеси, які сформували XX століття i продовжують формувати XXI, - урбанізація та індустріалізація. Тобто перехід більшої частини працівників з сільського господарства в промисловість та більшої кількості сільського населення в міста. Будьяка надзвичайна ситуація посилює ті тенденції, які вже були закладені в суспільстві та з більшою потужністю знищує з соціальної складової, те що існувало, але не мало розвитку. Такою надзвичайною ситуацією і стала пандемія COVID-19.

Пандемія зумовила певний «соціальний ефект» та вплинула й прискорила розвиток наступних тенденцій:

1) тенденцію гуманізації та цінності людського життя. Весь світ, незалежно від політичних моделей та типів політичних режимів 
відреагував на початкову хвилю пандемії готовністю обмеження свободи заради безпеки.

«Соціальний ефект» пандемії COVID-19: глобальне зростання громадської участі, добровільна взаємодія людей; загальна біда активізувала волонтерство; участь брендів в благодійності - нова норма [8].

2) тенденцію глобалізації в умовах ізоляції: єдність інформаційного та політичного простору. Ментально люди знаходяться у спілкуванні з усім світом, мають доступ до будь-якої інформації, а фізично прив'язані до того місця де мешкають.

3) тенденцію універсальності онлайн послуг. Повний перехід всього економічного обороту в онлайн, від сфери доставлення до освіти. Ізоляція та бажання збереження зв'язку із зовнішнім світом прискорює розвиток онлайн послуг.

«Соціальний ефект» пандемії COVID-19: використання інтернету - більше не опція, а необхідність; традиційна торгівля залишається в форматі супермаркетів; різке зростання індустрії доставлення; заміна традиційних лекцій онлайн-курсами; поява агрегаторів курсів різних університетів; заняття та самостійна робота в будь-який час в будьякому місці; у виробництво освітнього контенту залучені всі ІТ-гіганти [8].

4) тенденцію надомної та дистанційної роботи. Зміна відносин працівника та роботодавця, громадянина і міста.

«Соціальний ефект» пандемії COVID-19: скорочення офісних працівників; зміна традиційного розпорядку дня; посилення контролю за результатом праці; народження та виховання дитини - не підстава переривати кар'єру [8].

5) «медикалізація» суспільства. Питання здоров'я громадянина стає не особистим, а суспільним.

«Соціальний ефект» пандемії COVID-19: розширення повноважень міжнародних організацій охорони здоров'я; готовність громадян йти на обмежувальні заходи заради безпеки (вимірювання температури в публічних місцях, обов'язкові маски для хворих); підвищення масштабу відповідальності держави за життя і здоров'я громадян; нові стандарти гігієни [8].

Слід зазначити, що поширення коронавірусу призвело до масового закриття підприємств у всьому світі, припиненню більшості виробництв. У доповіді Світового банку «Перспективи світової економіки» говориться про те, що після різкого скорочення, викликаного пандемією COVID-19, обсяги світового виробництва виростуть у 2021 році на 4\%, однак цей приріст буде істотно нижче прогнозованого до пандемії [9]. Через зниження ділової активності та введення обмежувальних заходів бізнес у всьому світі зіткнувся 3 рецесією і зазнає значних збитків, зростає безробіття.

За даними Державної служби статистики України, кількість зайнятого населення у віці 15-70 років за 9 місяців 2020 року, у порівнянні з 9 місяцями 2019 року, скоротилася на 627 тис. осіб та становила 16,0 млн осіб. Рівень зайнятості населення у віці 15-70 років скоротився з 58,3\% до 56,5\%.

Кількість безробітного населення (за методологією Міжнародної організації праці) у віці 15-70 років за 9 місяців 2020 року, у порівнянні з 9 місяцями 2019 року, зросла на 182 тис. осіб та становила 1,6 млн осіб. Рівень безробіття населення (за методологією 
Міжнародної організації праці) у віці 15-70 років зріс з 8,1\% до 9,3\% робочої сили [2].

Станом на 1 січня 2021 року послуги державної служби зайнятості отримували 1,2 млн громадян, 3 них 459 тис. осіб мали статус безробітного (табл. 1), що на 36\% більше, ніж на відповідну дату минулого року [2].

Таблиця 1

Окремі характеристики зареєстрованих безробітних станом на 1 січня 2021 року

\begin{tabular}{|c|c|}
\hline Характеристика & $\begin{array}{c}\text { У загальній кількості зареєстрованих } \\
\text { безробітних }\end{array}$ \\
\hline За статтю: & $\begin{array}{l}\text { чоловіки - } 201 \text { тис. осіб (або 44\%), } \\
\text { жінки - } 258 \text { тис. осіб (або 56\%). }\end{array}$ \\
\hline За віковими групами: & $\begin{array}{l}30 \% \text { - у віці до } 35 \text { років; } \\
29 \% \text { - у віці від } 35 \text { до } 44 \text { років; } \\
26 \% \text { - у віці від } 45 \text { до } 55 \text { років; } \\
\text { 15\% - понад } 55 \text { років. }\end{array}$ \\
\hline За освітою: & $\begin{array}{l}\text { 49\% - вища освіта, } \\
34 \% \text { - професійно-технічна, } \\
17 \% \text { - загальна середня освіта. }\end{array}$ \\
\hline $\begin{array}{l}\text { За видами } \\
\text { економічної } \\
\text { діяльності: }\end{array}$ & $\begin{array}{l}21 \% \text { - раніше були зайняті у сільському, } \\
\text { лісовому та рибному господарстві; } \\
18 \% \text { - у сфері торгівлі; } \\
15 \% \text { - у переробній промисловості; } \\
12 \% \text { - у державному управлінні, обороні, } \\
\text { обов'язковому соціальному страхуванні. }\end{array}$ \\
\hline $\begin{array}{l}\text { За професійними } \\
\text { групами: }\end{array}$ & $\begin{array}{l}18 \% \text { - працівники з обслуговування, } \\
\text { експлуатації устаткування та машин; } \\
17 \% \text { - сфери торгівлі та послуг; } \\
15 \% \text { - службовці та керівники; } \\
12 \% \text { - представники найпростіших } \\
\text { професій; } 11 \% \text { - фахівці. }\end{array}$ \\
\hline
\end{tabular}

Як видно з таблиці 1, перш за все, пандемія COVID-19 завдала удар по сферах діяльності, в яких традиційно зайнято більше жінок, ніж чоловіків, - це індустрія розваг, готельно-ресторанний і туристичний бізнес, роздрібна торгівля. Крім того, багатьом жінкам довелося відмовлятися від роботи заради турботи про дітей, оскільки школи й дитячі садки виявилися закриті.

Протягом карантину було запроваджено низку законодавчих змін, спрямованих на підтримку людей, які втратили роботу, і тих, хто перебуває під загрозою звільнення: істотно спрощено процедуру реєстрації безробітного, збільшений розмір допомоги по безробіттю, розширено коло осіб, які мають право на отримання такої допомоги [10].

Пандемія обернулася істотними витратами для всіх регіонів, що розвиваються. Ризики негативного розвитку ситуації превалюють, і жоден регіон не застрахований від нових спалахів захворювання, логістичних складнощів з розподілом вакцин, фінансових проблем в умовах підвищеного рівня заборгованості, а також можливості тяжких довготривалих наслідків пандемії для економічного зростання і доходів [11]. 
Спад безробіття може мати наступні три стадії:

Перша стадія - початкова. Люди намагаються орієнтуватися та вижити. На цьому етапі спостерігається різке скорочення зайнятості та збільшення числа невдач в бізнесі.

Друга стадія - адаптації. На цій стадії спостерігається процес відновлювання 3 переривчастими перемогами й втратами у сфері зайнятості. Велика частина роботи, яку люди дійсно знаходять неформальна, ненадійна та непостійна. Держава зіткається 3 проблемою падіння податкових надходжень.

Третя стадія - прискорення. Деякі галузі швидко відновляться, але інші, такі як готельний бізнес та туризм, займуть набагато більше часу. Позаду залишаться низькооплачувані робітники та жителі сільської місцевості.

На період дії карантину та при введенні жорстких карантинних заходів здійснилися заходи державної підтримки зайнятості населення та бізнесу:

- одноразова матеріальна допомога у розмірі 8000 гривень, тим, чия сфера потрапляє під заборону через посилення карантинних заходів;

- одноразова матеріальна допомога суб'єктам господарювання для збереження робочих місць;

- компенсація виплат за єдиний соціальний внесок;

- погашення податкового боргу;

- податкові канікули;

- матеріальна допомога для фізичних осіб - підприємців з дітьми до 10 років;

- компенсації по частковому безробіттю;

- кредитні канікули для бізнесу «5\%-7\%-9\%» [12].

Проте, поряд із запропонованими заходами, першочерговими діями з боку держави для забезпечення економічного зростання та переходу спаду безробіття з початкової стадії до стадії прискорення, мають стати: виплати державної матеріальної допомоги безпосередньо підприємствам для збереження робочих місць та працевлаштування фахівців; допомога працівникам перейти на затребувану роботу; автоматизація для поліпшення, а не для заміни; управління постійними змінами.

Особливою сферою, що вимагає пильної уваги й підтримки 3 боку держави, на наш погляд, $€$ зайнятість молоді. Економічні наслідки пандемії посилюють вразливість молодих людей на ринку праці, через те, що молодь частіше людей старшого віку знаходиться на тимчасовій та неповній зайнятості, отже частіше стикається 3 високим ризиком втрати роботи та доходу. Також, заходи щодо обмеження свободи пересування, соціального дистанціювання та закриття навчальних закладів вплинули на ментальне здоров'я молоді, багато сімей опинилися в ситуації домашнього насильства [13]. Серед антикризових заходів допомоги молоді під час швидкого розвитку тенденцій, спричинених пандемією, слід виділити кілька основних напрямів (табл. 2): освіта, працевлаштування, підтримка вразливих груп. 
Заходи підтримки молоді державою

Таблиця 2

\begin{tabular}{|c|c|}
\hline Напрям & Заходи \\
\hline Освіта & $\begin{array}{l}\text { забезпечення учнів технікою для навчання, } \\
\text { враховуючи матеріально-технічні обмеження та } \\
\text { особливі потреби окремих груп учнів; } \\
\text { вдосконалення змістовної частини освітніх } \\
\text { програм; } \\
\text { інтеграція неформальної системи навчання до } \\
\text { системи освіти [14]; } \\
\text { підвищення професійної підготовки викладачів; } \\
\text { запровадження гнучких механізмів фінансової } \\
\text { та іншої допомоги (пряма фінансова допомога } \\
\text { випускникам ВНЗ; збільшення розміру стипендій). }\end{array}$ \\
\hline Працевлаштування & 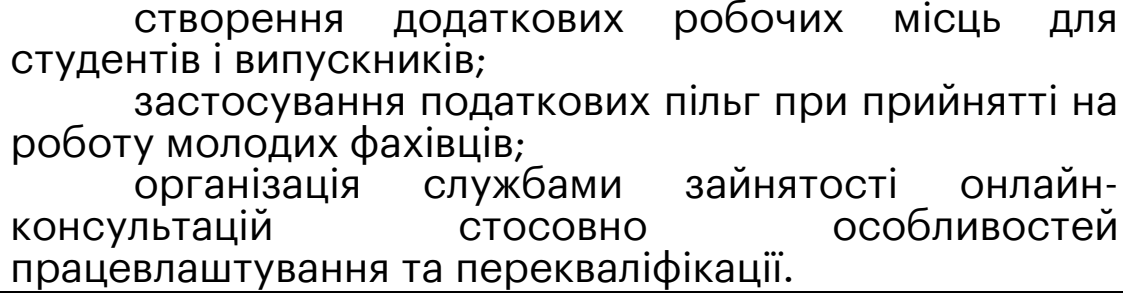 \\
\hline $\begin{array}{l}\text { Підтримка } \\
\text { вразливих груп }\end{array}$ & $\begin{array}{l}\text { налагодження зворотного зв'язку } \\
\text { психологічна підтримка молодих людей; } \\
\text { підтримка жертв насильства (створення сайту, } \\
\text { на який можуть звернутися молоді люди, які } \\
\text { зіткнулися з насильством); } \\
\text { допомога молодим сім'ям та сім'ям з дітьми } \\
\text { (додаткова матеріальна допомога для сімей з низьким } \\
\text { доходом; заходи для батьків, які працюють - } \\
\text { оплачувана відпустка по догляду за дітьми, якщо їх } \\
\text { дитячий сад або школа виявилися закриті). }\end{array}$ \\
\hline
\end{tabular}

Слід звернути увагу, що інноваційні та соціально-економічні трансформації зумовлюють зміни професійно - кваліфікаційної структури зайнятості на ринку праці й висувають нові вимоги до професійних знань, умінь та навичок працівників [15].

Між діяльністю та результатом завжди стоять навички. Hard skills та soft skills - основні види навичок, які використовує людина у роботі для досягнення своїх цілей. Hard skills («хардскілз», англ. hard skills "тверді навички») - технічні навички, пов'язані 3 діяльністю, яка виконується, в області формалізованих технологій. Soft skills ( “софтскілз», англ. soft skills - «м'які навички» або «гнучкі навички») навички, що виражаються в здатності ефективно мислити та спілкуватися [16]. Сьогодні молода людина повинна бути готова до зміни декількох професій протягом свого професійного життя. Поряд 3 hard skills, які демонструють професійні компетенції, посилюється вплив soft skills, які необхідні кожному для повноцінного розвитку особистості та досягнення успіху. Дослідження, проведені Гарвардським університетом, Фондом Карнегі та Стенфордським дослідницьким центром, прийшли до висновку, що $85 \%$ успіху в роботі походить від добре розвинених soft skills і навичок роботи 3 людьми, та тільки 15\% успіху в роботі залежить від технічних навичок і знань hard skills [17]. Однак, єдиного переліку гнучких навичок не існує. У світовому дослідженні World Economic Forum в Future of Jobs report виділено 35 гнучких навичок, які розділені на 3 ключових групи: здібності, базові навички, крос-функціональні навички [18]. 
Також зазначено, що прогалини в навичках дуже високі, оскільки у наступні п'ять років змінюються затребувані навички на різних посадах. До основних навичок і групам навичок, які, на думку роботодавців, будуть зростати до 2025 року, відносяться такі групи, як критичне мислення, аналіз, розв'язання проблем, а також навички самоврядування, такі як активне навчання, стійкість, стресостійкість та гнучкість [18]. Сучасні технології розвиваються так динамічно, що знання часом застарівають. За таких умов, на ринку праці у претендентів на робочі місця цінуються: бажання вчитися, розвиватися та вдосконалюватися; здатність і готовність швидко та успішно опановувати будь-яку техніку та технологію; здорове прагнення просунутися по кар'єрних сходах. Гнучкі навички допомагають обробляти бурхливий потік інформації, впевнено почувати себе не тільки в професії, а й у житті. Сучасний фахівець повинен володіти професійною мобільністю, гармонійно розвивати soft skills поряд з hard skills та бути конкурентоспроможним.

Висновки та перспективи подальших досліджень. Проведений аналіз показав, що пандемія COVID-19 прискорила системні зміни, які були очевидні до ії виникнення. Людство зіткнулося 3 непередбаченими викликами, серед яких досить різкий перехід до вимушеної цифровізації всіх процесів, нові форми роботи та стрімке зростання безробіття. Враховуючи особливості темпу розвитку сучасних тенденцій суспільства, виникає потреба вдосконалення наявних та розвитку нових навичок працівників, які допоможуть адаптуватися до збільшеної швидкості змін. Тому, для запобігання проблем пов'язаних з дефіцитом кваліфікованих працівників, масовим безробіттям та зростанням нерівності необхідно:

1. модифікувати систему освіти для підготовки спеціалістів, які будуть готові до нової економіки; адже, роботодавці налаштовані на цифровізацію робочих процесів, включаючи значне розширення віддаленої роботи.

2. посилювати розвиток soft skills; щоб орієнтуватися в нових ситуаціях для розв'язання проблем з якими раніше не стикалися, людині необхідно розвивати такі навички, як: адаптивність, креативність, розв'язання проблем і підприємницькі навички.

3. залучати інвестиції в навчання; надзвичайно важливо підвищення соціальної відповідальності бізнесу для активної підтримки трудового потенціалу шляхом перекваліфікації, підвищенні кваліфікації, можливості отримання додаткової професії.

\section{Література:}

1. Наслідки епідемії COVID-19 та карантинних заходів для провідних секторів економіки України. Дослідження за результатами глибинних інтерв'ю з власниками та топ-менеджерами українських компаній. Київ-Харків: Видавець О. А. Мірошниченко, 2020. 188 с.

2. Офіційний сайт Державної служби статистики. URL: www. ukr.stat.gov.ua.

3. Дистанційна робота в Україні. Серпень 2020. EY Knowledge Analysis, ONS, BLS, YouGov and Harris Poll surveys and Gartner. URL: http://publications.chamber.ua/2020/Human\%20Capital/EY AmCham Remote\%20work Presentation August 2020.pdf?fbclid=lwAROdrD89gl OHm1Q9WbUjpNKe4paDFDXvt-- 7fAEGTIbZeEKY69Z-GzqDrY. 
4. Soft Skills у студентів поколінь «Y» та «Z» як вимога сучасного ринку праці. Франкофонія в умовах глобалізації і полікультурності світу: збірник тез II Міжнародної науково-практичної конференції 19 березня 2020 р. Тернопіль: ТНПУ ім. В. Гнатюка, 2020. С. 372-374.

5. Kalenyuk I., Grishnova O., Tsymbal L., Djakona A., Panchenko E. (2020) Formation of intellectual corporatecapital: methods and moderntrends. Bulletin the National academy of sciences of the Republic of Kazakhstan. Vol. 1. No. 383. 2020. Pp. 182-191.

6. Колот А., Герасименко О., Ярмолюк-Крьок К. Сфера праці в умовах глобальної соціоекономічної реальності 2020: виклики для України. Die Friedrich-Ebert-Stiftung. Київ, 2020. 33 с.

7. Про зайнятість населення: Закон України. Відомості Верховної

Ради (BBP), 2013, № 24, ст.243. URL: https://zakon.rada.gov.ua/laws/show/5067-17.

8. Consumers and the new reality. Preparing for changing customer needs, behaviors and expectations. KPMG International URL: https://assets.kpmg/content/dam/kpmg/xx/pdf/2020/06/consumersand-the-new-reality.pdf.

9. World Bank Publications: Global Economic Prospects - January 2021: United States, World Bank Group. 2020, 270 pp.

10. Офіційний сайт Державної служби зайнятості. URL: https://www.dcz.gov.ua/.

11. World Development Report 2019: The Changing Nature of Work By the: Washington, DC, World Bank, 2019, 151 pp.

12. Про соціальну підтримку застрахованих осіб та суб'єктів господарювання на період здійснення обмежувальних протиепідемічних заходів, запроваджених 3 метою запобігання поширенню на території України гострої респіраторної хвороби COVID-19, спричиненої коронавірусом SARS-CoV-2: Закон України № 1071-IX. URL: https://zakon.rada.gov.ua/laws/show/1071-20\#Text.

13. United nations, special issue on covid-19 and youth. URL: https://www.un.org/development/desa/dspd/wpcontent/uploads/sites 222/2020/04/YOUTH-FLASH-Special-issue-on-COVID-19-1.pdf.

14. Становище молоді в Україні: аналітичний звіт / робоча група $\mathrm{OOH}$ у справах молоді. Київ 2019. 80 с. URL: https://ukraine.unfpa.org/.

15. Сучасні тенденції розвитку ринку праці в Україні: наукова доповідь / Джинчарадзе Н. Г., Боков О. В., Гулевич О. Ю., Вітряк Т. Б., Шостак І.В., Куліков Г.Т., Красівський Д. О., Савченко Н. В., Савенко О. О., Літвінчук Л. Й. Київ: ІПК ДСЗУ, 2018. 42 с.

16. Сучасні назви Soft i Hard skills - що це? URL: https://stsaltiv.gov.ua/useful-info/suchasni-nazvi-soft-i-hard-skills.

17. Дослідження проведені Гарвардським Університетом, Фондом Карнегі та Стенфордським Дослідницьким Центром. URL: https://www.nationalsoftskills.org/downloads/Mann-1918-

Study of Engineering Educ.pdf.

18. World Economic Forum Platform for Shaping the Future of the New Economy and Society. URL: http://www3.weforum.org/docs/WEF Future of Jobs 2020.pdf.

References:

1. Naslidky epidemiji COVID-19 ta karantynnykh zakhodiv dlja providnykh sektoriv ekonomiky Ukrajiny. Doslidzhennja za rezuljtatamy 
ghlybynnykh interv'ju z vlasnykamy ta top-menedzheramy ukrajinsjkykh kompanij. Kyjiv-Kharkiv: Vydavecj O. A. Miroshnychenko, 2020. 188 s.

2. Oficijnyj sajt Derzhavnoji sluzhby statystyky. URL: www. ukr.stat.gov.ua.

3. Dystancijna robota v Ukrajini. Serpenj 2020. EY Knowledge Analysis, ONS, BLS, YouGov and Harris Poll surveys and Gartner. URL: http://publications.chamber.ua/2020/Human\%20Capital/EY_AmCham Remote\%20work_Presentation_August_2020.pdf?fbclid=IwAR̄OdrD89gi OHm1Q9WbUjpNKe4paDFDXvt--_7fAEḠTIbZeEKY69Z-GzqDrY.

4. Soft Skills u studentiv pokolinj " $Y$ " ta " $Z$ " jak vymogha suchasnogho rynku praci//Frankofonija $v$ umovakh ghlobalizaciji i polikuljturnosti svitu: zbirnyk tez II Mizhnarodnoji naukovo-praktychnoji konferenciji 19 bereznja 2020 r. Ternopilj: TNPU im. V. Ghnatjuka, 2020. S. 372-374.

5. Kalenyuk I., Grishnova O., Tsymbal L., Djakona A., Panchenko E. (2020) Formation of intellectual corporatecapital: methods and moderntrends. Bulletin the National academy of sciences of the Republic of Kazakhstan. Vol. 1. No. 383 (2020). Pp. 182-191.

6. Kolot A., Gherasymenko O., Jarmoljuk-Krjok K. Sfera praci v umovakh ghlobaljnoji socioekonomichnoji realjnosti 2020: vyklyky dlja Ukrajiny. Die Friedrich-Ebert-Stiftung. Kyjiv, 2020. 33 s.

7. Pro zajnjatistj naselennja: Zakon Ukrajiny. Vidomosti Verkhovnoji Rady (VVR), 2013, \# 24, st.243. URL: https://zakon.rada.gov.ua/laws/show/5067-17.

8. Consumers and the new reality. Preparing for changing customer needs, behaviors and expectations. KPMG International URL: https://assets.kpmg/content/dam/kpmg/xx/pdf/2020/06/consumersand-the-new-reality.pdf.

9. World Bank Publications: Global Economic Prospects - January 2021: United States, World Bank Group. 2020, 270 pp.

10. Oficijnyj sajt Derzhavnoji sluzhby zajnjatosti. URL: https://www.dcz.gov.ua/.

11. World Development Report 2019: The Changing Nature of Work By the: Washington, DC, World Bank, 2019, 151 pp.

12. Pro socialjnu pidtrymku zastrakhovanykh osib ta sub'jektiv ghospodarjuvannja na period zdijsnennja obmezhuvaljnykh protyepidemichnykh zakhodiv, zaprovadzhenykh z metoju zapobighannja poshyrennju na terytoriji Ukrajiny ghostroji respiratornoji khvoroby COVID-19, sprychynenoji koronavirusom SARSCoV-2: Zakon Ukrajiny \# 1071-IKh. URL: https://zakon.rada.gov.ua/laws/show/1071-20\#Text.

13. United nations, special issue on covid-19 and youth. URL: https://www.un.org/development/desa/dspd/wpcontent/uploads/sites /22/2020/04/YOUTH-FLASH-Special-issue-on-COVID-19-1.pdf.

14. Stanovyshhe molodi v Ukrajini: analitychnyj zvit / robocha ghrupa OON u spravakh molodi. Kyjiv 2019. 80 s. URL: https://ukraine.unfpa.org/.

15. Suchasni tendenciji rozvytku rynku praci v Ukrajini: naukova dopovidj / Dzhyncharadze N.Gh., Bokov O.V., Ghulevych O.Ju., Vitrjak T.B., Shostak I.V., Kulikov Gh.T., Krasivsjkyj D.O., Savchenko N.V., Savenko O.O., Litvinchuk L.J. Kyjiv: IPK DSZU, 2018. 42 s.

16. Suchasni nazvy Soft i Hard skills - shho ce? URL: https://stsaltiv.gov.ua/useful-info/suchasni-nazvi-soft-i-hard-skills. 
17. Doslidzhennja provedeni Gharvardsjkym Universytetom, Fondom Karneghi ta Stenfordsjkym Doslidnycjkym Centrom. URL: https://www.nationalsoftskills.org/downloads/Mann-1918-

Study_of_Engineering_Educ.pdf.

18. World Economic Forum Platform for Shaping the Future of the New Economy and Society. URL: http://www3.weforum.org/docs/WEF Future of Jobs 2020.pdf.

Modern Ukrainian society is going through a difficult stage of economic and social transformation. Due to the crisis caused by the COVID-19 pandemic, Ukrainian businesses in 2020 ended up on the verge of survival. Such negative social phenomena as unemployment, low standard of living, and social stratification are being strengthened.

In times of crisis, some companies shrink, reallocate their resources, change their priorities, and change their staff requirements. The best companies understand what direction to move in today, what personnel is needed, what knowledge, skills and abilities will be required in the future, the more competitive they will be in the labour market.

A particular area that requires close attention and support from the state is youth employment. The pandemic's economic impact increases the vulnerability of young people in the labour market, as young people are more likely than older people to be in temporary and part-time employment, and therefore more likely to face a high risk of losing their jobs and income.

Priority actions on the part of the state to ensure economic growth and the decline in unemployment should be: payment of state material assistance directly to enterprises to save jobs and employ specialists; assistance to employees to switch to popular jobs; automatization to improve, not to replace; management of permanent changes.

We should note that innovative and socio-economic transformations lead to changes in the professional and qualification structure of employment in the labour market and put forward new requirements for employees' professional knowledge, skills, and abilities. Today, a young person should be prepared to change several professions during their professional life. Along with hard skills, which demonstrate professional competencies, the influence of soft skills increases. Soft skills are necessary for everyone to fully develop their personality and achieve success.

Modern technologies are developing so dynamically that knowledge sometimes becomes outdated. Under such conditions, in the labour market, job seekers are valued for: the desire to learn, develop and improve; the ability and willingness to quickly and successfully master any technique and technology; a healthy desire to move up the career ladder. Flexible skills help process the rapid flow of information, feel confident not only in the profession but also in life. 